\title{
Degradation Processes in the Contact Layers of Forming Tools
}

Jiří Hrubý, Vladimíra Schindlerová, Josef Rentka

Faculty of Mechanical Engineering, VŠB-Technical University Ostrava, 17. listopadu 2172/15, 70833 Ostrava - Poruba. Czech Republic, E-mail: jiri.hruby@vsb.cz, vladimira.schindlerova@vsb.cz, josef.rentka.st@ vsb.cz

The article deals with cyclical abrasive wear of the surface of forming tools. At this stage the research focused on the genesis of stress in the contact between a deformed material and a tool in the cold bulk forming process. The experiments were conducted in the simple configuration of the upsetting test. The article presents the results of abrasive wear by a combination of materials of examined samples and upsetting plates. The abrasive wear in the used material specimens was analysed comparatively in the form of the wear factor by the finite element method. Two intersecting phenomenological fields represent the output for the examined material combinations. Firstly, it is a formulation of the dependencies of the maximum depth increase of the surface wear. The argument is the number of exposure cycles. At the same time, the topology of degradations and the resulting roughness in the space of the exposed surface were examined.

Keywords: Cyclical Abrasive Wear, Wear Factor, Roughness, Wear Depth

\section{References}

[1] HRUBÝ, J., RENTKA, J., SCHINDLEROV`8, V., KREJČÍ, L., ŠEVČÍKOVÁ, X. (2013). Possibilities of prediction of service life of forming tools. Manufacturing Technology, Vol. 13, No. 2, pp. 178-181, ISSN 1213-2489.

[2] BIBA, N., STEBUNOV, S., MUNTINGA, H. (2005). Increasing of Tool Life in Cold Forging by Means of FEM Simulation. In: International Conference «New Developments in Forging Technology» in Fillbach, Germany, ISBN 3-88355-342-5.

[3] ASM Handbook, Vol. 19, Fatigue and fraction. (1996). ASM International. Product Code 06197G. ISBN 0-87170385-8, $341 \mathrm{p}$.

[4] ESPER, F. J., SONSONIO, C. M. (1997). Fatigue Design for PM Components. European Powder Metallurgy Association. Shrewsbury.

[5] BANNANTINE, J. A. et al. (1990). Fundamentals of Metal Fatigue Analysis. New Jersey: Prentice Hall.

[6] GROENBAEK, J., BIRKER, T. (2000). Innovations in cold forging die design. J. Mater. Process. Technol., Vol. 98, Issue 2, pp 155-161, ISSN 0924-0136.

[7] KNOERR, M., LANGE, K., ALTAN, T. (1994). Fatigue failure of cold forging tooling: causes and possible solutions through fatigue analysis. J. Mater. Process. Technol., Vol. 46, Issue 1-2, pp 57-71, ISSN 0924-0136.

[8] FALK, B., ENGEL, U., GEIGER, M. (1998). Estimation of tool life in bulk metal forming based on different failure concepts. J. Mater. Process. Technol., Vol. 80-81, pp 602-607, ISSN 0924-0136.

[9] LEE, G.-A., IM, Y.-T. (1999).Finite-element investigation of the wear and elastic deformation of dies in metal forming. J. Mater. Process. Technol., Vol. 89-90, pp 123-127, ISSN 0924-0136.

[10]LEE, Y. Ch., CHEN, F. K. (2001). Fatigue life of cold-forging dies with various values of hardness. J. Mater. Process. Technol., Vol. 113, pp 539-543, ISSN 0924-0136.

[11]SAROOSH, M. A., LEE, H.-C., IM, Y.-T., CHOI, S.-W., LEE, D.-L. (2007). High cycle fatigue life prediction of cold forging tools based on workpiece material property. J. Mater. Process. Technol., Vol. 191, pp 178-181, ISSN 0924-0136.

[12]LEE, H.-C., LEE, Y., LEE, S.-Y., CHOI, S., LEE D.-L. IM, Y.-T. (2008). Tool life prediction for the bolt forming process based on high-cycle fatigue and wear. J. Mater. Process. Technol., Vol. 201, pp 348-353, ISSN 09240136.

[13]JASIONOWSKI, R., PODREZ-RADZISZEWSKA, M., ZASADA, D. (2011). Cavitation erosion resistance of the chosen aluminum alloys. Manufacturing Technology, Vol. 11, No. 11, pp. 22-28, ISSN 1213-2489

[14]ČUBAN, J., CALONIUS O., PIETOLA, M., JERSÁK J. (2011). Fatigue life and surface integrity measurements of EN S355J2 steel used in hydraulic components. Manufacturing Technology, Vol. 11, No. 11, pp. 5-11, ISSN 1213-2489.

[15] MÜLLER, M., VALÁŠEK, P. (2010). Interaction of steel surface treatment by means of abrasive cloth and adhesive bond strength. Manufacturing Technology, Vol. 10, pp. 49-57, ISSN 1213-2489. 